\title{
6
}

\section{Witnessing e-waste through participatory photography in Ghana}

\section{Peter C. Little}

\section{Introduction}

Drawing on extended ethnographic research in Agbogbloshie, an urban scrapyard in Accra, Ghana that has become the subject of a contentious electronic waste (e-waste) narrative, this chapter explores the extent to which citizen ${ }^{1}$ photography and similar participatory visual research efforts augment contemporary toxic studies in general and e-waste studies in particular. Attuned to the visual promises, politics, and possibilities of photography in toxic landscapes (Peeples 2011; Davies 2013; Barnett 2015; Rosenfeld et al. 2018), the chapter contends that engaging with participatory visualization and documentation can provide vital contextualization for debates grappling with the toxic injustices and environmental politics of e-waste labor. I explore how and why visual techniques in participatory action research matter in global environmental justice studies in general and postcolonial e-waste studies in Ghana in particular. This participatory e-waste visualization project accounts for the critical role of researcher positionality and reflexivity in efforts to bear witness to and make sense of lived experiences of e-waste. Taking a participatory photography approach that recognizes embodied ways of knowing e-waste, this project attempts to go beyond the massive archive of contentious natural and humanist photography focused on Africa and the "prism of misery" (Keane 1998, 2) that 
too often typifies transatlantic and North-to-South visions of environmental destruction in Africa.

Amid air monitoring technologies, risk mitigation machines, optimistic NGOs (nongovernmental organizations), journalists, environmental and social scientists, makerspace engineers, slum tourists, and photographers, Agbogbloshie is a vibrant urban scrap-metal market. It is a space and place where workers engage in hazardous metal extraction to supply global copper and aluminum markets. For most who have turned to Agbogbloshie as a site of e-waste research, there is an effort to somehow extend an ethos of care for those living and working in this notorious West African hot spot of "toxic colonialism" (Koné 2009). ${ }^{2}$ But, what seems less common in projects focused on Agbogbloshie are efforts to showcase how these workers are creative postcolonial agents actively documenting and communicating their own lived experience, pollution situation, and e-waste vitality. In short, the chapter asks: what happens when e-waste workers are involved image makers? What does this participatory photography do to and for representations of Agbogbloshie? To what extent can this alternative visualization shift understandings of a place and space that has become a central node of global e-wasteland and digital pollution narratives? Moreover, how does engagement with this alternative approach to witnessing and knowing e-waste draw attention to or renew critical discussion of researcher positionality and ethnographic reflexivity?

Workers in this site, for example, have too often been understood as e-waste recycling laborers who foreground their experience of pollution and environmental health risk. But, representations of Agbogbloshie as a site of e-waste toxicity and ruination are not the only stories being told. Lived experiences of e-waste, it turns out, are far more complicated. In light of this, the chapter navigates how e-waste "perceptual regimes" (Poole 1997) can be reconfigured and meshed with the overlapping projects of environmental justice (EJ) and toxics knowledge production. It will be argued that e-waste worker images advance contemporary and future e-waste and digital pollution studies by providing much-needed perceptual inversion and representational plurality (Bleiker and Kay 2007). They teach us new ways of seeing and visioning e-waste contextualization and perhaps even the environmental justice challenges experienced in Agbogbloshie (Akese and Little 2018). My aim here, then, is to turn to a participatory photography project in Agbogbloshie to stimulate critical discussion of the ways in which alternative e-waste visioning can transform how e-wasteland politics in Ghana are told, seen, and responsibly contextualized. Participatory photography, in this way, offers a critical perspective on embodied ways of knowing and practices of bearing witness to e-waste pollution, Furthermore, photography itself offers a compelling counterpoint to systemic 
post-truth politics in the Trump era. For example, one of the most powerful uses of photography-for-proof in recent times was on January 20, 2017, the day of Donald Trump's inauguration. The image spread quickly. Visual proof concluded that Barak Obama was the obvious champion of recent inaugural turnout statistics, despite the Trump Administration's efforts to convince the public otherwise. In short, the citizen showing for Obama's inauguration on January 20, 2009 was clear evidence of victory. This visual proof sparked a debate that highlighted the first of many disappointments with and opposition to techniques of visualization coming from the Trump White House. This all dovetails with recent trends in post-truth politics. As Lyons (2017) points out:

The "post-truth" environment we live in seems, at least in part, to be a function of the current confusing information flow and how politicians, governments and others use it towards their own ends. It remains to be seen what longer term effects this will have on journalism generally and photojournalism in particular but the power of the still image remains undeniable, even if some choose to ignore inconvenient truths. (Lyons 2017, 2)

This contemporary reorientation of the power of visualization can provide a platform for "making new sense" (Hastrup 1995) of the complexities and confusion that come with current and future representations of the e-waste pollution problem that put Agbogbloshie on the global toxics map.

\section{Situating Ghana in the global e-wasteland narrative}

The globalization of electronic discard is a robust and growing domain of scholarship and activism (Lepawsky 2018). The places where this discard shows up - most notably China, India, Bangladesh, and Ghana - are often described by academics and activists as digital dumping grounds and high-tech slums where informal economies and ecologies are marked by a tangle of toxic substances, contentious state oversight and NGO intervention, local corruption, extreme poverty, and scrap-metal market politics. One such place is Agbogbloshie, an urban scrap market in Accra, Ghana, that has attracted numerous international environmental NGOs, makerspace activists, environmental health scientists, slum tourists, journalists, photographers, and social scientists. Visitors can witness what they have been told about this place and space of digital "wastelanding" (Voyles 2015). They encounter a smoky scrap market zone of intense metal recovery, a site where the burning of e-waste to recover valuable metals, especially copper and aluminum, is an everyday activity. It is a space of ram- 
pant toxicity, an environment of lead, mercury, cadmium, PCBs (polychlorinated biphenyls), and airborne contaminants, including polybrominated diphenyl ethers (PBDEs) that present numerous environmental health risks (Caravanos et al. 2011, 2013; Feldt et al. 2014; Wittsiepe et al. 2015; Kyere et al. 2016). Agbogbloshie is also a place of contentious green NGO risk mitigation intervention that tends to overlook the complex lived experience of the postcolonial bodies and subjectivities navigating the web of social, environmental, and economic risks associated with toxic e-waste recycling (Little 2016).

Located on the banks of the Korle lagoon in Accra, Ghana, the Agbogbloshie scrapyard is located within a vibrant informal settlement and economy where commercial, industrial, and residential zones overlap and land rights struggles persist. Adjacent to the scrap market is the biggest fresh food market in Accra, the Agbogbloshie market. Old Fadama, an informal settlement, also sits to the east of the scrap market. Opposite the scrap market and along the Abossey Okia road are a host of industrial and commercial enterprises including a paint factory, a brewery, a Pepsi bottling plant, a timber market, a meat market, branches of various banks, and a commercial bus depot. About $90 \%$ of the roughly 5,000 workers at Agbogbloshie also make the nearby Old Fadama informal settlement their home (Prakash et al. 2010). Old Fadama residents are constantly threatened by the Accra Metropolitan Assembly (AMA), an urban authority that has recently been the focus of public scrutiny after the AMA forcefully evicted residents following the disastrous flooding of the Korle lagoon in May 2015. The flooding killed nearly 300 people and caused an explosion at a gas station that made international headlines.

While the broader Agbogbloshie and Old Fadama area has a deep history of land management politics dating back to the colonial period (Grant 2006; Afenah 2012; Stacey and Lund 2016), the establishment of the scrap market dates to the early 1990s when city authorities, in an attempt to decongest the central business district of Accra, relocated hawkers and Accra's yam market to the edge of the Korle lagoon. The relocation of Accra's yam market in 1993 laid the ground for the scrapyard as various services such as vehicle repair and spare parts trading, welding, auto mechanics, and tire servicing were crucial to the operation of the yam trucks (Grant 2006). With diminished agricultural opportunities and compounding intertribal conflicts in Ghana's northern territory, people moved south to Accra in search of alternative livelihoods. However, in the absence of job opportunities in the formal sector and in the niche parts of the informal sector, and in addition to rising housing costs and rent in Accra for the urban poor, most of these migrant labors found residency in Agbogbloshie or Old Fadama. In a time marked by rapid population growth in the wider Agbogbloshie area, truck repair and ancillary services transformed into a major 
scrap market which now also serves as the major hub for e-waste processing and employs about 5,000 people (Prakash et al. 2010).

\section{Agbogbloshie's contentious visual economy}

Despite widely circulated journalistic accounts of Agbogbloshie as a dumpsite for the world's electronic discard, it is much more than an e-wasteland. Workers, for example, talk about Agbogbloshie as a market, not a landfill. Despite this representational confusion, toxic e-waste recycling is ongoing and continues to be a source of critical environmental health risk in Agbogbloshie, as workers spend long hours each day engaging in market metal extraction that is highly toxic. When discarded electronics and electrical equipment end up in Agbogbloshie, the discard containing copper and aluminum is collected, but not as raw copper. Workers first extract the electrical components from the range of exhausted machines that end up at the scrapyard, such as junked cars, buses, and delivery trucks which contain copper-based wires. The quickest and easiest way to extract the copper embedded in these forms of waste is to burn it. The process involves igniting petroleum-based materials, like discarded tires or refrigerator insulation, and tossing bundles of copper wire on the flame until all the plastic insulation disappears. These workers burn the e-waste at several designated burn sites at Agbogbloshie. Locally described as "the burners," they face all the bodily risks of the "burning class," as Marx and today Peter Sloterdijk would have it. Their toxic labor comes with a body burden cost. For example, epidemiological studies have shown that workers experience significant exposures to lead, mercury, cadmium, PCBs, and PBDEs (Caravanos et al. 2013; Grant et al. 2013; Wittsiepe et al. 2015).

After an international team of epidemiologists "scientifically" confirmed the risks of this wage labor, an international solutions-based environmental NGO came on the scene, an organization called Pure Earth (formerly Blacksmith Institute; www.pureearth.org). Their primary mission: "eliminating burning" at Agbogbloshie and developing a scrap worker health promotion campaign. While there is no shortage of NGO critique to highlight in the case of Pure Earth, I want to single out Pure Earth's approach to formalizing e-waste recycling in Ghana. I suggest the organization actually further marginalizes the workers who do the burning for several reasons. First, the workers don't have direct access to the facility and do not receive training in how to use the granulators for stripping the wires. Second, using the granulators slows down the copper extraction process. Third, since the granulators run on electricity - a constant energy infrastructure challenge in Ghana - it costs money to use the facility. Lastly, since the 


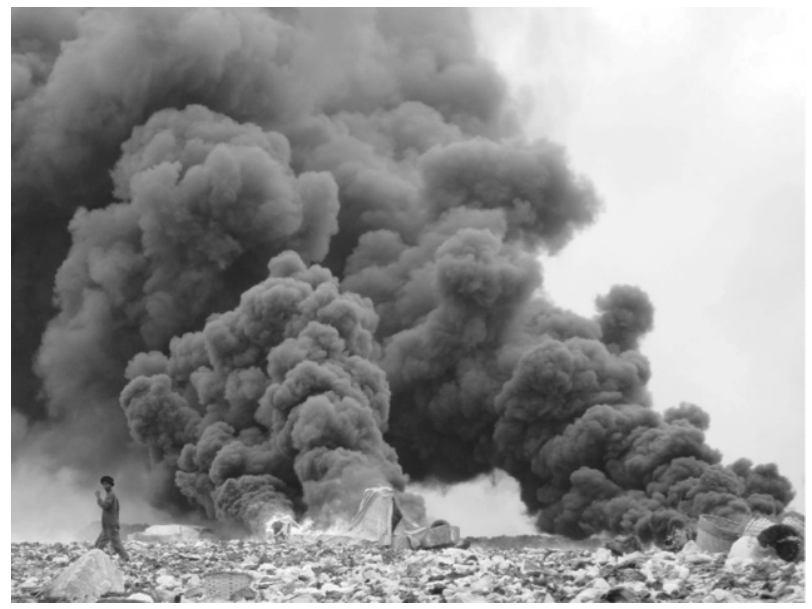

6.1 An urban authority fire. Photo by Peter Little.

facility primarily processes waste electrical equipment, usually large-diameter cables, coming from Ghana's electrical utility company, the facility seems to only serve clients who either have a "formal" relation with Pure Earth or who have a direct supply of large-diameter cables. The burners lose out on this business opportunity because the e-waste collected by those working directly with the burners only have the capacity to extract small-diameter cables from junked machines in the scrapyard. Without the ability to deliver large-diameter cables to the facility, the burners are left out of the purported "economic development" goals of the e-waste recycling project.

Agbogbloshie exhibits a unique case of "electronic pyropolitics" (Little 2016, forthcoming) - a postcolonial struggle over toxic fire, burning, and extreme open-air incineration. It is always ablaze, always smells of burning plastics and metals, and it happens to be the case that it is not always workers engaged in copper extraction who are responsible for these highly toxic fires. One photograph I took in July 2016 (see Figure 6.1) depicts a fire started by the Accra Metropolitan Assembly (AMA), an urban agency that, ironically, has a mission "to improve the quality of life of the people of the city of Accra, especially the poor, vulnerable and excluded, by providing and maintaining basic services and facilities in the areas of education, health, sanitation and other social amenities, in the context of discipline, a sense of urgency and commitment to excellence."

This image tells a complex postcolonial and "pyropolitical" story (Minter 2016; Little forthcoming; see also Marder 2015). It signals the state-based disciplinary forces at play in Agbogbloshie. The image tells the all-too-common story of violent displacement and demolition. ${ }^{3}$ It cracks open the incineration 
politics of social and environmental justice, and exposes and sustains the politics of confusion and paradoxical nature of state and non-state interventions of risk mitigation. One could deconstruct this image further, but what is perhaps most interesting is that when e-waste workers engage in pollution visioning and documentation, they capture and focus on the usual toxic suffering of classic Agbogbloshie imagery. But, on the other hand, these workers also witness and document radically different things and lived experiences. They raise awareness about that which is in their everyday material environment. That perceptual difference makes a difference, especially for how one witnesses, experiences, and knows e-waste pollution and violence in Ghana's urban margins.

\section{Vital e-waste contextualization and the work of worker images}

I never intended to develop a project centered on e-waste participatory photography. Rather, this interest emerged from my own ethnographic research experience in Agbogbloshie. During fieldwork in Agbogbloshie in the summer of 2016, I was talking to a group of workers about the risks they face when burning e-waste to extract copper. We sat under a makeshift shelter made from the roof of a junked trotro, the minibuses many Ghanaians use to travel. They began by talking about the smoke from burning e-waste and how it impacts their breathing and sleeping, but they also started to show me their hands, feet, arms, and legs. They pointed to wounds, especially burns, on their bodies, an experience that shifted my own visual ethnographic focus and feeling: that maybe it was best that the workers take their own photos and share them with me if they felt comfortable doing so. What transpired was a grassroots participatory photography emphasis that was not my original goal. Following this fieldwork experience, workers began using their cell phones to snap pictures of their wounded bodies. Workers would send me images of their cuts and burns on a weekly basis, and the more they shared these images with me, the more I started to realize that this practice of image sharing was changing my own vision of Agbogbloshie and the workers making a living there. While their burnt and cut bodies became a medium of self-expression, it is important to consider how even these worker images are mediated by my own positionality as an American anthropologist and clear outsider. The fact of the matter is that the audience of the shared images is as powerful as the images themselves (Rose 2016). As the white American researcher, I was clearly the primary audience of these images. But, nevertheless, the practice of sharing these images was a way to make sure I knew that bodily harm from toxic e-waste extraction was 
still ongoing. On a return fieldwork trip in 2018, I asked the workers why they sent me these photos, and one of the burners explained: "it helps you see what we do here. This is how it is here. We know this. We send photos to tell you how it is here. You understand?" On the one hand, this response made perfect sense to me, but it also never did help clarify for me why workers continued to send me photos. The workers never tell me directly that they send images to help raise awareness about the toxic injuries they face as e-waste burners in Agbogbloshie, but they are explicit about teaching me something with their own images, even if that means turning the camera toward torched copper wires, burnt bodies, or even more playful group selfies. What I came to realize is that sustaining connection and keeping in touch with me - the American anthropologist in Agbogbloshie - had a lot to do with it, but not exactly everything to do with it.

When e-waste workers engage in this toxic risk documentation they are actively contextualizing, communicating, and indexing the embodied social and environmental health risks they face. One might call this a process of vital e-waste contextualization. Showing and marking vital signs of toxic risk contextualizes the experience of toxic burden, victimization, and marginalization within Ghana's e-waste recycling sector. But as visual anthropologists have pointed out, image making is a political practice with various consequences. Reminiscent of the "crisis of representation" (Marcus and Fischer 1986) critique emerging in the 1980s in anthropology, multiple problems and politics of representation emerge when privileged outsiders (usually white and from the global North) create representations of marginalized populations (usually dark and from the global South) in order to expose inequalities and disparities in social, political, and economic systems. There is an overwhelming sense that image making always risks being a practice of image taking, a way of doing representational appropriation in a "contact zone" (Pratt 1992) where vibrant power relations persist. All representational strategies, that is, directly or indirectly serve the interests of the image makers, no matter the shifts in representational ethos and edits to practices of objectification and dehumanization. Even the emergence of participatory photography in my ethnographic research serves my own interests as an anthropologist attempting to better understand the lived experience of e-waste workers in Ghana. Like others studying toxic environments, I am caught in a familiar conundrum. A frontand-center challenge, it seems, is that even while trying to find new ways to represent our toxic world, we confront, no matter our representational strategies, the risks of "hazardous aesthetics" (Rosenfeld et al. 2018) and challenges of "visual interventions" (Pink 2007; Peeples 2011; Harper 2012; see also Harper 2002). 
More recently, visual anthropologists contend that

relying on images of suffering bodies as a visual strategy of depicting injustice or inequality is at odds with making systemic social, economic, and political oppression visible ... [I]mages of suffering bodies tend to naturalize connections between violence and already marginalized peoples. Furthermore, they do not ultimately work to make structural violence visible by (1) obscuring the mechanisms and perpetrators of violence, (2) not disrupting dominant conceptual frameworks, and (3) not leaving room for solutions. (Stone 2015, 179)

Beyond simply a technology of documentation, taking photos can have intended and unintended self-serving consequences that can dehumanize e-waste laborers in Agbogbloshie, even for photographers emphasizing humanistic portraiture. For example, during an interview focusing on his project Agbogbloshie: Digital Wasteland, the German photographer Kevin McElvaney noted that, "At first, Agbogbloshie caught my attention because it's really photogenic, but the environmental, socio-economic, political and ethical problems there forced me to see it with my own eyes. I don't like to judge things when I haven't seen it for real and everything I found about Agbogbloshie on the web seemed so unreal, but after I'd been there, I realized that it's even worse" (Donson 2014).

What I want to suggest here is that e-waste worker images, as a representational strategy for exploring environmental health risk, labor, and life in Agbogbloshie, are not simply toxic "shock value" images, but instead new forms of everyday life documentation and cultural vitality that make Agbogbloshie a place and space that is more than e-waste toxicity. What these workers face is what they digitally capture and what they face can be many things, but it is rarely the burning piles of copper wire that constitute the dominant optic of circulating narratives on Agbogbloshie. Each worker image I receive inspires me to ask what workers key into, what they account for, and why they share the images they share. Additionally, this grassroots e-waste visualization experience has inspired me to take more seriously the extent to which participatory photography can provide a new platform for bearing witness to e-waste struggle in a toxic, urban, and postcolonial scrapyard landscape, especially at a time when emergent forms of instrumentalization, computation (Gabrys 2016), and digitization are shaping how we make sense of and understand environmental problems. In this way, my interests in e-waste visualizations draw inspiration from recent discussion and theory in "digital anthropology," or doing ethnography in a contemporary world that "accounts for how the digital, methodological, practical and theoretical dimensions of ethnographic research are increasingly intertwined" (Pink et al. 2016, 1).

Amid the toxic smoke, it is critical to remember that Agbogbloshie is Ghana's most active scrap metal market, with iron, steel, brass, copper, and aluminum 


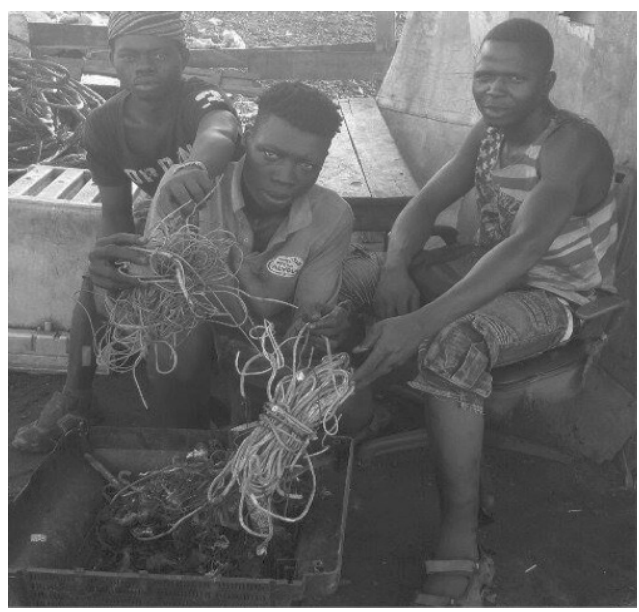

6.2 Workers showing their collected copper wires. Photo by Abdul Rahim.

being the most sought-after market metals. The workers making up the informal labor force here come mostly from villages in northern Ghana where economic hardships caused by colonialism have long been known to be a stimulus for southward labor migrations (Plange 1979). As shown in Figure 6.2, when these workers turn the camera on themselves, they purposively emphasize their copper wire collections. In this image, taken by one the sub-chiefs or managers of a primary group of copper burners, pre-scorched copper wires, objects with market value, are made to be the center of attention. As Jacob, one of the longtime workers among this group of copper burners told me during my visit in July 2017, "Copper is why we here. We be here for dat. All dis be copper. No work in north. This be work." Given this dominant metal in the scrapyard, it is easy to see why copper is foregrounded in this image. Copper is also a major reason why these workers migrate to Agbogbloshie from their villages in the north. When this image was taken, the price of copper was US $\$ 2.10$ a pound, a commodity that is significantly more valuable than the ground nuts that many of these workers' families farm in Ghana's northern region.

For me, these e-waste worker images are not simply additives to the ethnographic method, but instead represent "an emerging platform for collecting, exploring, and expressing ethnographic materials” (Hsu 2014, 1). Many, if not most, ethnographies of pollution and environmental justice today involve a complex political ecology of data, what some in the digital humanities call our age of "augmented empiricism" (Hsu 2014) and what Trump critics signal as an age of "environmental data justice" (Dillon et al. 2017). Of course, the turn to the visual and visual data is nothing new in the social sciences, nor is it new for 
discard studies focusing on the global e-waste trade and its local manifestation in spaces and places like Agbogbloshie. If anthropological debates over the ethnographic use of images in toxic postcolonial spaces actually reproduces or risks the reproduction of colonialism or colonial acts of representation, then what do citizen-based images really do? What do these marginalized urban e-waste worker images do? What visual standpoint epistemologies and ontologies do they offer? What politics of representation do these images generate and communicate? Perhaps more importantly, what politics of representation do or can these images circumvent? Researchers have discussed Agbogbloshie as a symbolic reminder of "toxic colonialism," but how might participatory photography operate as a method of visual decolonization, a technique of vital contextualization that can augment understandings of labor and social life in electronic "discardscapes" (Lepawsky 2018)?

Other worker photos help communicate and translate the "blessing" of the scrap metal market itself, a topic that no studies of Agbogbloshie account for. Agbogbloshie workers have a primary meeting place for metal market meetings, negotiations, and blessings that they call "Gaza." As shown in Figure 6.3, one worker named Ibrahim took my camera and waited for a good time to take a shot during a meeting and blessing at Gaza. I didn't immediately ask why he spontaneously took my camera, but I later learned that it was because it would have been inappropriate or disrespectful for me to take a picture because many of the meeting attendees did not know who I was. Soon after, Ibrahim returned to where I was sitting and I learned that the meeting and blessing had nothing to do with e-waste. It had nothing to do with praying for greater pollution control or government waste management policy and action. Instead the gathering occurred to discuss and voice worker opinions, concerns, and ideas about the

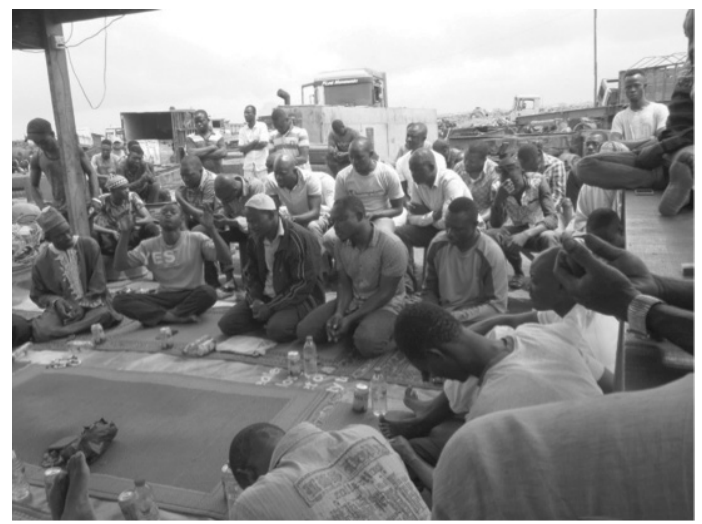

6.3 Scrap worker meeting and market blessing. Photo by Ibrahim Akarima. 
social, political, spiritual, and economic management of the scrap market. As Ibrahim told me, "The workers want the copper here. The iron and the aluminum here. We bless it so it come here." After taking a few more pictures of the meeting and blessing, Ibrahim repeated: "They be blessing the copper. Blessing the market."

They were not debating and discussing lead and cadmium exposures and body burdens, nor were they organizing a meeting to respond to NGO interventions to control pollution emitting from Agbogbloshie. Again, this "other" story matters. Even while critical relations between toxic bodies and environments (Roberts and Langston 2008) ought to remain a concern of e-waste studies in Agbogbloshie, these relations must also consider the dominant role of Muslim cultural, religious, and hereditary chieftaincy dynamics at play. This is what sustains social life in the market and what ultimately informs North-South labor migrations, movements, and experiences of people navigating the actual political ecology of e-waste risk. Inspired by Beck's (2006) idea that "Without techniques of visualization, risks are nothing at all," we need to make on-the-ground facts visible to fully visualize and come to terms with the actual toxic reality experienced in and among those making a living in Agbogbloshie.

Still images of e-waste workers in Agbogbloshie do many things. They communicate postcolonial waste management, inequities in the global toxic waste trade, but also friendship, tribal relations, and bodily distress. The latter topic has had a strong focus within photo-ethnographic work in medical anthropology. For example, medical anthropologist Paul Farmer has been criticized for his use of images of sick bodies to make visible what he calls "structural violence." He admits that "the use of such images is problematic but sometimes necessary in order to stir privileged populations to do something about global systems of inequality" (Stone 2015, 180). The logic of this angle is that "the problem of making structural violence visible is that social, political, and economic structures that are to blame for the violence are very difficult to photograph because they are very difficult to see" $(2015,180)$. One could argue that citizen visioning practices like participatory photography don't necessarily "capture” experience (images are powerful, but don't replace bare life experience itself), but they do "expose" or "share" lived context to the world of observers and those bearing witness. Furthermore, images can and often do generate empathy. When workers share photos they are, in some fast digital way, "sharing" their life experience with me. These images are shared by the purported "victims" of e-waste toxicity, but a problem emerges when images of suffering bodies are deployed "to illustrate injustice or structural violence locates all of the violence, the shame, and the danger of the violence in the suffering body of the victim rather than the assailant for the simple reason that the assailant is nowhere to be seen" (Stone 
2015, 183). But, what happens when postcolonial subjects are the image makers and those bearing witness to e-waste pollution and contextualization? What happens when Agbogbloshie workers themselves visualize "landscapes of affect" (Moore et al. 2003: 31), when they themselves enable us to better understand "the simultaneous imagination and fabrication of inner selves, social bodies, and environmental milieu" (ibid.)? These are important questions for advancing not only e-waste studies, but environmental ethnographies of environmental justice and toxics citizen science writ large.

\section{Conclusion}

In this chapter, I have tried to show how in the process of making and sharing images, e-waste workers in Agbogbloshie are engaging in a participatory photography practice that accounts for the multiple ways of witnessing and knowing e-waste. Ultimately, their images stretch and go beyond the usual e-wasteland narrative. As an ethnographer being shown what matters, and especially what matters beyond the "singular story" (Mkhwanazi 2016) of toxic digital destruction and extraction so common in representations of Agbogbloshie, I have begun to find these images to be necessary tools for making sense of Agbogbloshie. Ironically, the digital devices we use as research tools might eventually end up back in Agbogbloshie or another toxic wasteland as salvageable digital discard. But, while not knowing where these tools may end up, I do know that these workers turn to images, including selfies, to share what matters of concern matter to them. Accordingly,

Rather than paralyze representational practices ... visual depiction of structural violence need not settle for a qualified visual strategy heavily bolstered by written or spoken analysis. Ethnographic reflexivity (in toxic studies) is a good strategy for many reasons, but it is not the only option. As the robust traditions of feminism and visual anthropology have argued, we should take the lead from the marginalized peoples who already work to make the abstract forces of [toxic] structural violence visible. (Stone 2015, 180)

How these workers show and share their experience of toxic suffering and violence is complicated by the fact that they don't necessarily turn the camera toward the postcolonial state nor toward objects of toxic destruction to communicate their "environmental” experience. For example, the workers didn't send me images of urban authorities evicting workers attempting to dwell in the Agbogbloshie scrapyard or shelters being demolished in Old Fadama, the adjacent settlement, to mitigate the risks of annual flooding along the Korle lagoon. 
In short, the e-waste worker images validate an on-the-ground lived experience that can be overlooked and lost amid the prism of toxicity and misery images that dominate the e-wasteland narrative of Agbogbloshie.

My ongoing e-waste participatory photography project, in this sense, speaks to an ethos of "pluralist photography" (Bleiker and Kay 2007, 168) attuned to power. As Bleiker and Kay (ibid.) put it, "Human relations cannot exist outside power. But the nature of pluralist photography minimizes the oppressive effects of these relations by consciously problematizing representation. The collaborative and dialogical nature of pluralist photography can provide ways through which multiple perspectives may be seen and validated." In light of this, I have come to realize that there are many benefits and even more challenges of doing participatory photography or collaborative photo-ethnography in Agbogbloshie. To start with, using photography to bear witness to e-waste lived experience is not necessarily a difficult thing to do. Taking pictures is a rather easy observational technique that even the poorest and most marginalized of the global South can engage. For the workers I engage with in Agbogbloshie, this is an easy way to participate in the visual storytelling that takes place in Agbogbloshie. On the other hand, the turn to grassroots participatory photography does not escape criticism nor necessarily lead to more ethical e-waste ethnography. In fact, anthropologists have rightly cautioned that visions of marginality and the practice of recycling the production of these representational strategies and visions can sustain marginality itself (Ferguson 2006). Some have even engaged with this important issue more directly in Ghana by encouraging consideration of the always contentious nature of ongoing "Black transatlantic visions" (Holsey 2013). These are research and representational concerns that have informed my way of thinking about and doing participatory photography in Agbogbloshie. Working in collaboration with Agbogbloshie workers to visualize Agbogbloshie was never my intended goal, but it became a focus once workers themselves began to voluntarily snap shots and send me images of their own making. In the process, I have experienced a personal transformation in how to position myself as a researcher. I am not just finding new ways to forge relationships with e-waste workers, but also learning how to relate to the images they share with me. For sure, worker images help me translate my own ethnographic experience and narrative. They help me find a way to understand and possibly make better sense of Agbogbloshie. Without a doubt, they draw attention to things I don't see. In the process of being shown what I don't see and therefor know about e-waste, they have helped me become more aware, self-critical, and reflexive as a researcher. Finally, participatory photography taught me about unforeseen ethics of research and representation that can emerge when navigating politics of pollution, participation, and the various environmental injustices of global electronic discard. 
As I have noted, most depictions of Agbogbloshie's e-waste workers highlight toxic labor practices (e.g., burning copper wires) and do so to expose the contentious nature of e-waste recycling matters of concern in Ghana and other "discardscapes" (Lepawsky 2018) of the global South. These e-waste representations, it turns out, have a charismatic quality and force that has consequences for contemporary waste theory and action (Lepawsky 2018; see also Liboiron 2016). In other words, "what makes e-waste charismatic is its capacity to act as an allegory of contemporary environmental crisis" (Lepawsky 2018,6). The e-waste environmental justice politics emerging in Agbogbloshie, then, are as much about environmental health crisis as they are shaped by a complex crisis of representation. What I am hoping to illustrate in my turn to workers' photographs of life and labor in Agbogbloshie is that these visualizations showcase the actual involvement of postcolonial agents in documenting their own lived experience. ${ }^{5}$ They also provide an example for how e-waste workers visually explore their own toxic e-waste situation and lived experience. This other technique of risk visualization can help advance critical and creative environmental health studies, synthesize the democratization of science and EJ advocacy efforts, and push the boundaries and intentions of visual ethnography in sites of toxic electronic discard more broadly. While participatory photography will certainly not fix all the problems and politics of representation in e-waste studies, this form of visualization can certainly lead to more creative research and action partnerships. At the very least, it opens up alternative epistemic possibilities within an ever-changing landscape of mixed-media pollution and discard studies.

\section{Notes}

1 In this chapter, I follow the approach to "citizenship" taken up by Ellison (1997), which suggests that citizenship is "a form of social and political practice born of the need to establish new solidarities across a range of putative 'communities' as a defense against social changes which continually threaten to frustrate such ambitions” (Ellison 1997, 712).

2 One of the first writings on e-waste dumping in Africa appeared in the late 1980s (see Brooke 1988), which emerged amid other works on "toxic terrorism" in Africa writ large (O’Keefe 1988).

3 For a description of the demolition campaign in Agbogbloshie and Old Fadama in 2015, see Lepawsky and Akese (2015).

4 The term originally comes from Galtung (1969).

5 Emerging scholarship on toxicological science and contamination politics in Senegal similarly highlights this need for greater attention to postcoloniality (Tousignant 2018). 


\section{References}

Afenah, A. 2012. Engineering a millennium city in Accra, Ghana: The Old Fadama intractable issue. Urban Forum, 23, 527-540.

Akese, G. and Little, P. C. 2018. Electronic waste and the environmental justice challenge in Agbogbloshie. Environmental Justice, 11(2), 77-83.

Barnett, J. T. 2015. Toxic portraits: Resisting multiple invisibilities in the environmental justice movement. Quarterly Journal of Speech, 101(2), 405-425.

Beck, U. 2006. Living in the world risk society. Economy and Society, 35(4), 329-345.

Bleiker, R. and Kay, A. 2007. Representing HIV/AIDS in Africa: Pluralist photography and local empowerment. International Studies Quarterly, 51, 139-163.

Brooke, J. 1988. Waste dumpers turning to West Africa. New York Times, July 17. http:// www.nytimes.com/1988/07/17/world/waste-dumpers-turning-to-west-africa.html? pagewanted $=$ all (last accessed February 3, 2020).

Caravanos, J., Clark, E. E., Fuller, R., and Lambertson, C. 2011. Assessing worker and environmental chemical exposure risks at an e-waste recycling and disposal site in Accra, Ghana. Journal of Health and Pollution, 1, 16-25.

Caravanos, J., Clarke, E. E., Osei, C. S., and Amoyaw-Osei, Y. 2013. Exploratory health assessment of chemical exposures at e-waste recycling and scrapyard facility in Ghana. Journal of Health and Pollution, 3, 11-22.

Davies, T. 2013. A visual geography of Chernobyl: Double exposure. International Labor and Working-Class History, 84, 116-139.

Davis, J.-M., Akese, G., and Garb, Y. 2019. Beyond the pollution haven hypothesis: Where and why do e-waste hubs emerge and what does this mean for policies and interventions? Geoforum, 98, 36-34.

Dillon, L. et al. 2017. Environmental data justice and the Trump Administration: Reflections from the Environmental Data and Governance Initiative. Environmental Justice, 10(6), 186-192.

Donson, T. 2014. Agbogbloshie: Digital wasteland. Dazed Magazine, February 26. http:// www. dazeddigital.com/photography/article/19008/1/agbogbloshie-digitalwasteland (last accessed February 3, 2020).

Ellison, N. 1997. Towards a new social politics: Citizenship and reflexivity in late modernity. Sociology, 31(4), 697-717.

Feldt, T., Fobil, J. N., and Wittseipe, J. 2014. High levels of PAH-metabolites in urine of e-waste recycling workers from Agbogbloshie, Ghana. Science of the Total Environment, 369-376.

Ferguson, J. 2006. Global Shadows: Africa in the Neoliberal World Order. Durham, NC and London: Duke University Press.

Gabrys, J. 2016. Program Earth: Environmental Sensing Technology and the Making of a Computational Planet. Minneapolis: University of Minnesota Press.

Galtung, J. 1969. Violence, peace, and peace research. Journal of Peace Research, 6(3), 167-191. 
Grant, R. 2006. Out of place? Global citizens in local spaces: A study of the informal settlements in the Korle Lagoon environs in Accra, Ghana. Urban Forum, 17, 1-24.

Grant, K., Goldizen, F., and Sly, P. 2013. Health consequences of exposure to e-waste: A systematic review. The Lancet Global Health, 1(6), 350-361.

Harper, D. 2002. Talking about pictures: A case for photo elicitation. Visual Studies, 17, 13-16.

Harper, K. 2012. Visual interventions and the "crisis in representation" in environmental anthropology: Researching environmental justice in a Hungarian Romani neighborhood. Human Organization, 71(3), 292-305.

Hastrup, K. 1995. A Passage to Anthropology: Between Experience and Theory. London and New York: Routledge.

Holsey, B. 2013. Black Atlantic Vvsions: History, race, and transnationalism in Ghana. Cultural Anthropology, 28, 504-518.

Hsu, W. F. 2014. Digital ethnography toward augmented empiricism: A new methodological framework. Journal of Digital Humanities, 3(1), 1-5.

Keane, F. 1998. Another picture of starving Africa: It could have been taken in 1984, or 1998. Guardian, June 8.

Koné, L. 2009. Pollution in Africa: A new toxic waste colonialism? An assessment of compliance of the Bamako Convention in Côte d'Ivoire. LLM dissertation, University of Pretoria.

Kyere, V. N., Greve, K., and Atiemo, S. A. 2016. Spatial assessment of soil contamination by heavy metals from informal electronic waste recycling in Agbogbloshie, Ghana. Environmental Health and Toxicology, 31.

Lepawsky, J. 2018. Reassembling Rubbish: Worlding Electronic Waste. Cambridge, MA: MIT Press.

Lepawsky J. and Akese, G. 2015. Sweeping away Agbogbloshie again. Discard Studies (blog). https:// discardstudies.com/2015/06/23/sweeping-away-agbogbloshie-again (last accessed February 3, 2020).

Liboiron, M. 2016. Redefining pollution and action: The matter of plastics. Journal of Material Culture, 21(1), 87-110.

Little, P. C. 2016. On Electronic pyropolitics and Pure Earth friction in Agbogbloshie. Toxic News, November 8.

Little, P. C. Forthcoming. Burning Matters: Life, Labor, and E-Waste Pyropolitics in Ghana. New York and Oxford: Oxford University Press.

Lyons, S. 2017. The purpose of photography in a post-truth era. Time, January 26. http:// time.com/4650956/photojournalism-post-truth/ (accessed February 3, 2020).

Marcus, G. E. and Fischer, M. M. J. 1986. Anthropology as Cultural Critique: An Experimental Moment in the Human Sciences. Chicago: University of Chicago Press.

Marder, M. 2015. Pyropolitics: When the World is Ablaze. London and New York: Rowman \& Littlefield.

Minter, A. 2016. The burning truth behind an e-waste dump in Africa. Smithsonian, January 13. http:/ / www.smithsonianmag.com/sciencenature/burning-truth-behind-e-wastedump-africa-180957597 (last accessed on February 3, 2020). 
Mkhwanazi, N. 2016. Medical anthropology in Africa: The trouble with a single story. Medical Anthropology, 35(2), 193-202.

Moore, D. S., Pandian, A., and Kosek, J. 2003. The cultural politics of race and nature: Terrains of power and practice. In. D. S. Moore, J. Kosek, and A. Pandian (eds), Race, Nature, and the Politics of Difference. Durham, NC and London: Duke University Press, pp.1-70.

O’Keefe, P. 1988. Toxic terrorism. Review of African Political Economy, 15(42), 84-90.

Peeples, J., 2011. Toxic sublime: Imaging contaminated landscapes. Environmental Communication: A Journal of Nature and Culture, 5(4), 373-392.

Pink, Sarah (ed.) 2007. Visual Interventions. New York: Berghahn Books.

Pink, Sarah et al. (eds) 2016. Digital Ethnography: Principles and Practice. London: Sage.

Plange, N.-K. 1979. Underdevelopment in northern Ghana: Natural causes or colonial capitalism? Review of African Political Economy, 6, 4-14.

Poole, D. 1997. Vision, Race, and Modernity: A Visual Economy of the Andean Image World. Princeton, NJ: Princeton University Press.

Prakash, S. et al. 2010. Socio-economic Assessment and Feasibility Study on Sustainable e-Waste Management in Ghana. Report by Ghana EPA, Green Advocacy Ghana, NVMP, VROMInspectie, and the Institute for Applied Ecology.

Pratt, M. L. 1992. Imperial Eyes: Travel Writing and Transculturation. London: Routledge.

Roberts, J. A. and Langston, N. (eds) 2008. Toxic bodies/toxic environments: An interdisciplinary forum. Environmental History, 13(4), 629-703.

Rose, G. 2016. Visual Methodologies: An Introduction to Researching with Visual Materials. London: Sage.

Rosenfeld, H., Moore, S., Nost, E., Roth, R. E., and Vincent, K. 2018. Hazardous aesthetics: A "merely interesting" toxic tour of waste management data. GeoHumanities, 4(1), 262-281.

Stacey, P. and Lund, C. 2016. In a state of slum: Governance in an informal urban settlement in Ghana. Journal of Modern African Studies, 54(4), 591-615.

Stone, L. K. 2015. Suffering bodies and scenes of confrontation: The art and politics of representing structural violence. Visual Anthropology Review, 31(2), 177-189.

Tousignant, N. 2018. Edges of Exposure: Toxicology and the Problem of Capacity in Postcolonial Senegal. Durham, NC: Duke University Press.

Voyles, T. B. 2015. Wastelanding: Legacies of Uranium Mining in Navajo Country. Minneapolis: University of Minnesota Press.

Wittsiepe, J., Fobil, J. N., and Till, H. 2015. Levels of polychlorinated dibenzo-p-dioxins, dibenzofurans (PCDD/Fs) and biphenyls (PCBs) in blood of informal e-waste recycling workers from Agbogbloshie, Ghana, and controls. Environment International, 79, 65-73. 